


\section{Beoordeling toepassing van de regeling Verplaatsing glastuinbouwbedrijven Gelderland}

Marc Ruijs, Jan Benninga, Gerben Jukema

Dit onderzoek is uitgevoerd door Wageningen Economic Research in opdracht van en gefinancierd door de provincie Gelderland. 
Marc Ruijs, Jan Benninga, Gerben Jukema, 2019. Beoordeling toepassing van de regeling Verplaatsing glastuinbouwbedrijven Gelderland. Wageningen, Wageningen Economic Research, Nota 2019-047. 22 blz.; 0 fig.; 4 tab.; 3 ref.

Dit rapport is gratis te downloaden op https://doi.org/10.18174/475805 of op www. wur. nl/economicresearch (onder Wageningen Economic Research publicaties).

(C) 2019 Wageningen Economic Research

Postbus 29703, 2502 LS Den Haag, T 07033583 30, E communications.ssg@wur.nl, www.wur.nl/economic-research. Wageningen Economic Research is onderdeel van Wageningen University \& Research.

\section{(cc) BY-NC}

Dit werk valt onder een Creative Commons Naamsvermelding-Niet Commercieel 4.0 Internationaallicentie.

(C) Wageningen Economic Research, onderdeel van Stichting Wageningen Research, 2019 De gebruiker mag het werk kopiëren, verspreiden en doorgeven en afgeleide werken maken. Materiaal van derden waarvan in het werk gebruik is gemaakt en waarop intellectuele eigendomsrechten berusten, mogen niet zonder voorafgaande toestemming van derden gebruikt worden. De gebruiker dient bij het werk de door de maker of de licentiegever aangegeven naam te vermelden, maar niet zodanig dat de indruk gewekt wordt dat zij daarmee instemmen met het werk van de gebruiker of het gebruik van het werk. De gebruiker mag het werk niet voor commerciële doeleinden gebruiken.

Wageningen Economic Research aanvaardt geen aansprakelijkheid voor eventuele schade voortvloeiend uit het gebruik van de resultaten van dit onderzoek of de toepassing van de adviezen.

Wageningen Economic Research is ISO 9001:2008 gecertificeerd.

Wageningen Economic Research Nota 2019-047 | Projectcode 2282200429

Foto omslag: Frans Blok/Shutterstock.com 


\section{Inhoud}

1

Inleiding $\quad \mathbf{5}$

1.1 Aanleiding 5

1.2 Doelstelling $\quad 5$

2

$\begin{array}{ll}\text { Methode en aanpak } & 6\end{array}$

2.1 Beoordelingscriteria doel verplaatsingsregeling 6

2.1.1 Inleiding 6

2.1.2 Volwaardigheid bedrijf $\quad 7$

2.1.3 Verplaatsing van het gehele bedrijf $\quad 8$

2.1.4 Behoud van het eigenaarschap 8

2.1.5 Behoud teelt(richting) 9

2.2 Potentiële aanvragers voor verplaatsingsregeling 9

3

$\begin{array}{ll}\text { Resultaten } & 10\end{array}$

3.1 Beschrijving subsidieaanvragen $\quad 10$

3.2 Beoordelingscriteria doel verplaatsing $\quad 11$

3.2.1 Volwaardigheid bedrijf 11

$\begin{array}{ll}3.2 .2 \text { Verplaatsing van het gehele bedrijf } & 13\end{array}$

3.2.3 Behoud van het eigenaarschap 13

3.2.4 Behoud van de teelt(richting) 13

$\begin{array}{ll}3.2 .5 \text { Samenvatting } & 13\end{array}$

$\begin{array}{lll}3.3 & \text { Potentiële aanvragen voor verplaatsing } & 14\end{array}$

4 Conclusies $\quad 16$

$\begin{array}{ll}\text { Literatuur en websites } & 17\end{array}$

$\begin{array}{lll}\text { Bijlage } 1 \text { Geraadpleegde deskundigen } & 18\end{array}$

Bijlage 2 Overzicht subsidieaanvragen voor de Regeling glastuinbouw 19

Bijlage 3 Documenten vereist bij indienen aanvraag voor verplaatsingssubsidie glastuinbouw Gelderland 20 



\section{$1 \quad$ Inleiding}

\section{$1.1 \quad$ Aanleiding}

Sinds 2009 is de regeling Verplaatsing glastuinbouwbedrijven Gelderland van kracht, waarmee de provincie Gelderland (solitaire) glastuinbouwbedrijven financieel ondersteunt bij het verplaatsen naar specifiek aangewezen gebieden met doorgroeimogelijkheden. Dit betreft het verplaatsen van bestaande toekomstvaste of volwaardige bedrijven naar twee intensiveringsgebieden (Bommelerwaard en Lingewaard) en drie regionale clusters voor glastuinbouwontwikkeling (Tuil, Elst en Voorst). Deze regeling is onderdeel van de Europese POP-regeling. Het is een tijdelijke regeling uitgaande van een investeringscyclus van 15 jaar. Het doel van de regeling is om volwaardige bedrijven doorgroeimogelijkheden te bieden in de intensiveringsgebieden.

Recente voorvallen in de praktijk wijzen erop dat sommige subsidieaanvragen niet geheel in lijn zijn met het doel van de regeling. Bedrijven zijn al afgeschreven en/of niet volwaardig. ${ }^{1}$

De vraag van het provinciebestuur van Gelderland is of en in welke mate zich dit heeft voorgedaan. Daarnaast vraagt de provincie zich af of de verplaatsingsregeling nog moet worden voortgezet met het oog op mogelijke toekomstige aanvragen van solitair gelegen glastuinbouwbedrijven.

\subsection{Doelstelling}

De provincie heeft behoefte aan een evaluatie van de regeling Verplaatsing glastuinbouwbedrijven Gelderland met de volgende twee doelen:

1. Het beoordelen of het intrinsieke doel van de regeling Verplaatsing glastuinbouwbedrijven Gelderland wordt gerealiseerd gezien de ingediende aanvragen.

Het is geen evaluatie van de regeling zelf, maar of de ingediende aanvragen passen bij het onderliggende liggende doel van de regeling: het toekomst bieden aan volwaardige glastuinbouwbedrijven om door te kunnen groeien bij verplaatsing naar een van de intensiveringsgebieden. Vanaf 2009 zijn 37 aanvragen ingediend.

2. Het verkennen of er potentieel toekomstige aanvragen van glastuinbouwbedrijven zijn, die aanspraak zouden kunnen maken op de verplaatsingsregeling. In beginsel gaat het hier om solitair gevestigde glastuinbouwbedrijven in alle gebieden, inclusief de extensiveringsgebieden in de Bommelerwaard en gemeente Lingewaard, maar exclusief de concentratiegebieden. De regeling staat daarnaast ook aanvragen van glastuinbouwbedrijven toe die al in de zogenoemde intensiveringsgebieden liggen. 


\section{$2 \quad$ Methode en aanpak}

\section{$2.1 \quad$ Beoordelingscriteria doel verplaatsingsregeling}

\subsubsection{Inleiding}

In overleg met de provincie zijn vier beoordelingscriteria voor het intrinsieke doel vastgesteld:

- Volwaardigheid bedrijf of volwaardig in gebruik

'Het gebruik van een agrarisch bedrijf dat naar de aard en omvang zodanig is dat het gehele inkomen van één persoon afkomstig is uit het bedrijf, de gehele arbeidsinzet aan het bedrijf besteed wordt en waarvan de continuïteit voor minimaal de afgelopen drie jaar is aangetoond' (Besluit Subsidieplafonds 2016 voor de Verordening POP3-subsidies provincie Gelderland).

Toetsing vindt plaats op basis van:

- het inkomen uit bedrijf voor minimaal één persoon

- arbeidsinzet voor minimaal één persoon

- continuïteit van het bedrijf in de afgelopen 3 jaar.

- Verplaatsing van het gehele bedrijf (van de solitaire locatie) naar het intensiveringsgebied of regionale glastuinbouwcluster

Toetsing vindt plaats of het bedrijf als geheel is verplaatst naar de nieuwe locatie in het intensiveringsgebied of regionale cluster. In sommige gevallen is de verplaatsing gekoppeld aan de uitbreiding van een bestaande locatie van de eigenaar in een intensiveringsgebied.

- Behoud van het eigenaarschap

De ondernemer is en blijft eigenaar in de nieuwe situatie.

Toetsing vindt plaats of het eigenaarschap van het bedrijf wordt voortgezet in de nieuwe situatie. In sommige gevallen is er gedeeld eigenaarschap.

- Behoud van teelt(richting)

Op het nieuwe bedrijf wordt dezelfde teelt van producten aangehouden.

Toetsing vindt plaats of de teeltrichting na verplaatsing wordt voortgezet. Wijziging van teeltrichting is géén reden om een aanvraag af te wijzen.

Met betrekking tot aanvragen voor de verplaatsingsregeling zijn twee situaties te onderscheiden: eigenaar en pachter van kassen. Voor de eigenaar is de situatie duidelijk. Ingeval van pacht van kassen kan de pachter, indien het minimaal de kassen 3 jaar pacht van de verpachter, ook een aanvraag voor verplaatsing indienen. In dat geval draagt de pachter zorg voor de sloop van de kassen op de oude locatie.

De provincie wenst ook inzicht of het eigenaarschap en de teeltrichting hetzelfde blijft of dat dit wijzigt. En of dit een trend is in de laatste jaren dat de verplaatsingsregeling van kracht was.

Om de evaluatie in deze studie te kunnen doen is de relevante documentatie bij de provincie opgevraagd, die bij een aanvraag voor de verplaatsingsregeling moet worden ingediend. Er is geen aanvullende informatie gebruikt nadat de provincie heeft besloten over de aanvraag.

Hierna zijn de beoordelingscriteria nader uitgewerkt. 


\subsubsection{Volwaardigheid bedrijf}

Volwaardigheid van het bedrijf is beoordeeld aan de hand van drie sub-criteria: inkomen uit bedrijf voor minimaal één persoon, arbeidsinzet voor minimaal één persoon en continuïteit in de afgelopen drie jaar.

\section{Continuïteit}

Het toekomstperspectief van bedrijven is af te lezen aan de continuïteitsverwachting van bedrijven. Simpel omschreven is continuïteit de verwachting dat een bedrijf over enkele jaren nog bestaat. In verband met bedrijfsverplaatsing is het voor het beoordelen van de continuïteit van bedrijven noodzakelijk dat van belangrijke financiële kengetallen resultaten uit het verleden beschikbaar zijn en een prognose wordt aangegeven met een daarbij horende onderbouwing.

Continuïteit of het perspectief daarvan, ook wel mate van toekomstvastheid genoemd, wordt volgens Van der Meulen et al. (2010) afgelezen aan de volgende kengetallen:

- rentabiliteit gedurende laatste vijf jaren

- solvabiliteit gedurende laatste vijf jaren, waarbij de situatie in het jaar van de bedrijfsverplaatsing het belangrijkst is

- leeftijd ondernemer

- beschikbaarheid van bedrijfsopvolger, gekoppeld aan leeftijd ondernemer.

\section{Toelichting}

De rentabiliteit is gedefinieerd als de opbrengst per $€ 100$,- kosten en is een kengetal in de bedrijfseconomische boekhouding. Meegenomen worden de directe teeltkosten en de indirecte kosten (die zijn niet toe te rekenen aan productie), exclusief de rentekosten. In de kosten zitten wel afschrijvingen. De waardering van eigen arbeid en kapitaal zijn daarin ook meegenomen. In een fiscale boekhouding ontbreekt de waardering van eigen arbeid en kapitaal. Hierdoor is de rentabiliteit op basis van cijfers uit de fiscale boekhouding wat hoger dan op basis van de bedrijfseconomische boekhouding.

De solvabiliteit is gedefinieerd als het eigen vermogen gedeeld door het totale vermogen, vanuit de fiscale balans. Zogenaamde stille reserves blijven buiten beschouwing. Stille reserves ontstaan als gevolg van een lagere waardering van grond en opstallen dan conform de marktsituatie zou mogen worden verwacht. Banken hanteren een minimum solvabiliteit om voor een lening in aanmerking te komen (circa 30\%). Hier zijn stille reserves wel bij inbegrepen.

Om een goed beeld te krijgen van de continuïteit wordt uitgegaan van een termijn van vijf jaar omdat de resultaten in de glastuinbouw (met name opbrengst per 100 euro kosten) grote schommelingen kunnen vertonen. Vaak zijn productprijsschommelingen hiervan de oorzaak.

Een gemiddelde rentabiliteit gedurende vijf jaar lager dan 95\% duidt op een zorgelijk financieel perspectief. Er is in zo'n situatie namelijk vijf jaar achtereen verlies gemaakt. De vergoeding voor arbeid van de ondernemer(s) wordt in de fiscale exploitatierekening betrokken uit de winst van een onderneming. Bij een verlies (rentabiliteit kleiner dan 100\%) wordt ingeteerd op de financiële reserves.

Een solvabiliteit lager dan 30\% berekend uit de fiscale balans duidt ook op een zorgelijk financieel perspectief en dus continuïteit, als gevolg van het financieel beleid en bedrijfsresultaten in het verleden. Eventuele stille reserves zouden een solvabiliteit lager dan 30\% omhoog kunnen brengen maar een gezonde financiële situatie is dit niet. De solvabiliteit is op langere termijn afhankelijk van de rentabiliteit. Een solvabiliteit van $30 \%$ (inclusief stille reserve) is de minimumeis van banken voor bedrijven om voor een lening in aanmerking te komen. Bij een rentabiliteit hoger dan 100 kunnen schulden beter worden afgelost en kan de solvabiliteit verbeteren.

Of bedrijfsopstallen waaronder glasopstanden, in meer of mindere mate afgeschreven zijn, is op zich geen indicator voor de toekomstbestendigheid van een bedrijf. Een lage moderniteit betekent een hogere toekomstige investeringsclaim en dus meer financieringslasten. Afschrijvingen drukken in 
geval van volledig afgeschreven opstallen niet meer op de exploitatierekening en bij een normale bedrijfsvoering zou mogen worden verwacht dat zo'n situatie samengaat met relatief weinig vreemd vermogen en dus een hogere solvabiliteit. Een bedrijfsverplaatsing, deels gefinancierd met vreemd vermogen, zal normaal gesproken tot een lagere solvabiliteit leiden.

In deze evaluatie is uitgegaan van de financiële gegevens behorende bij de subsidieaanvraag. Dit betreft gegevens over de afgelopen drie jaar. Op basis van deze cijfers is de gemiddelde rentabiliteit en solvabiliteit beoordeeld.

Behalve de cijfers over de afgelopen jaren is ook de prognose in de beoordeling betrokken. Indien de prognose een substantiële verbetering van bovengenoemde kengetallen laat zien, dient hier een reële argumentatie aan ten grondslag te liggen. Het verschil tussen de resultaten in de laatste drie jaar en de prognose is een belangrijke indicator. Onzekerheid over productprijzen dient in acht genomen te worden.

Continuïteit van bedrijven is ook verbonden met de leeftijd van de ondernemer(s) en de aanwezigheid van een opvolger. Voor de regeling Verplaatsing glastuinbouwbedrijven Gelderland is deze informatie niet als zodanig gevraagd en is dus ook niet meegenomen in deze evaluatie. Uit een aantal aanvragen was deze informatie wel af te leiden.

\section{Arbeidsinzet door minimaal één persoon}

Vanuit het oogpunt van volwaardigheid van een bedrijf dient een bedrijf werkgelegenheid te bieden aan ten minste één persoon. Het aantal volwaardige arbeidskrachten per bedrijf is afgeleid uit de arbeidskosten in de fiscale exploitatierekening voor zover het 'vreemde arbeid' betreft. Er is een normbedrag van $€ 28.500$ per jaar gehanteerd, gebaseerd op een volwaardige arbeidskracht (Vermeulen, 2016).

\section{Inkomen uit bedrijf voor minimaal één persoon}

Bij elke aanvraag heeft de provincie Gelderland een toets uitgevoerd of de subsidieaanvraag aan de gestelde voorwaarden voldoet. Zo ook voor het inkomen uit bedrijf. Er is door de provincie Gelderland geen concreet bedrag aangegeven dat als minimuminkomen uit bedrijf voor één persoon zal worden gehanteerd in de beoordeling.

Als maat voor het inkomen uit bedrijf voor één persoon is in deze evaluatie de vergoeding van de berekende arbeid voor de ondernemer gehanteerd. Dit ligt volgens normen van Wageningen Economic Research op circa $€ 50.000$ per jaar en is voor de gehele subsidieperiode 2009-2017 aangehouden.

\subsubsection{Verplaatsing van het gehele bedrijf}

Om voor de verplaatsingsregeling in aanmerking te komen dient de gehele bedrijfslocatie te worden verplaatst waarop de aanvraag betrekking heeft. Dit is de basis voor de beoordeling in deze evaluatie. Behalve de bedrijfslocatie kan daarnaast ook zogenaamd sprokkelglas worden ingebracht. De verplaatsing kan worden gerealiseerd door nieuwvestiging in een van de intensiveringsgebieden, door aankoop van een bestaand bedrijf of door uitbreiding van een bestaande locatie van de aanvrager in het intensiveringsgebied. De informatie is afgeleid uit de situatieschetsen van het bestaande bedrijf én het nieuwe bedrijf.

\subsubsection{Behoud van het eigenaarschap}

Nagegaan is of het eigenaarschap wordt voortgezet in de nieuwe situatie. Dit geldt ook voor de situatie dat de grond waarop de kassen staan minimaal drie jaar is gepacht. In sommige gevallen kan er gedeeld eigenaarschap zijn: in dat geval moet de aanvrager voor minimaal de helft van het bedrijf eigenaar zijn. Als er aandelen zijn, moet minimaal de helft in bezit zijn van de aanvrager. Bij een minderheidsaandeel $(<50 \%$ ) wordt de aanvraag niet gehonoreerd en is dit in de beschikking aangegeven. De informatie is afgeleid uit de verstrekte documentatie. 


\subsubsection{Behoud teelt(richting)}

Een aandachtspunt in de verplaatsingsregeling is dat de teelt(richting) in de nieuwe situatie wordt voortgezet. Bij verandering van teelt wordt een zeker risico genomen, waarvan het effect niet goed valt in te schatten. Het risico kan (deels) worden ondervangen door het inzetten van (extra) teeltbegeleiding. De situatie ten aanzien van de teelt(richting) vóór en ná verplaatsing is opgevraagd en meegenomen in deze evaluatie. Wijziging van teelt(richting) is overigens geen reden om een aanvraag af te wijzen.

\subsection{Potentiële aanvragers voor verplaatsingsregeling}

Het aantal glastuinbouwbedrijven in Gelderland is in kaart gebracht met cijfers uit de CBS Landbouwtelling (CBS, 2018). Het in kaart brengen van het aantal potentiële verplaatsers op basis van deze CBS cijfers was niet mogelijk. Er is geen onderscheid te maken naar glastuinbouwbedrijven in extensiveringsgebieden, solitaire vestigingen en intensiveringsgebieden, omdat deze indeling niet parallel loopt aan de gemeente-indeling binnen het CBS. Daarnaast is niet bekend welke bedrijven al gebruik hebben gemaakt van de verplaatsingsregeling.

Op basis van een inventarisatie door het Projectbureau Herstructurering Tuinbouw Bommelerwaard (PHTB) is een werkwijze bepaald om het aantal potentiële verplaatsers in kaart te brengen. PHTB heeft op basis van data van CBS, GGN, KvK, luchtfoto's, etc. voor de bedrijven in de gehele Bommelerwaard het oppervlak bebouwd (kas en gebouwen), leeftijd kas en gemiddelde nokhoogte bepaald. Dit betreft de (solitair gelegen) bedrijven in het gehele buitengebied (inclusief extensiveringsgebied). Daarnaast is op kaarten de situatie in de intensiveringsgebieden in de Bommelerwaard zichtbaar gemaakt. De data hebben betrekking op 2016.

Met behulp van de gebiedskennis van adviseurs en consultants (zie bijlage 1 ) is de lijst met bedrijven doorgelopen. Daar de provincie Gelderland een indicatie van het aantal potentiële verplaatsers wil hebben, is niet gestreefd naar het exacte aantal.

De lijst met bedrijven in het buitengebied (inclusief extensiveringsgebieden) is gerangschikt naar bedrijfsomvang. Vervolgens is bekeken of de bedrijven (uit 2016) anno 2018 nog bestaan. Hierbij is de volgende pragmatische lijn gevolgd, waarbij een periode van tien jaar (2016-2025) in ogenschouw is genomen:

- Bedrijven $>5.000 \mathrm{~m}^{2} \quad$ alle bedrijven zijn toekomstbestendig en zijn een potentiële verplaatser

- Bedrijven tussen 3.000 en $5.000 \mathrm{~m}^{2}$ de helft van de bedrijven is toekomstbestendig en is een mogelijke verplaatser

- Bedrijven < $3.000 \mathrm{~m}^{2} \quad$ bedrijven zijn in beginsel niet toekomstbestendig. Zijn geen potentiële verplaatsers. Kunnen als sprokkellocatie ingebracht worden in een aanvraag door een derde partij.

Bij deze indeling is meegenomen de beschikbare kennis over de huidige situatie van de bedrijven bij de adviseurs. Dit hield in dat bedrijven vanaf $5.000 \mathrm{~m}^{2}$ toekomstperspectief hebben door de specifieke teelt en/of gebruiksfunctie van de kas (veredeling en/of opkweek, handel). In de klasse van 3.000 tot $5.000 \mathrm{~m}^{2}$ heeft ongeveer de helft van de bedrijven toekomstperspectief door de nicheteelt of veredelingsfunctie. Daarnaast kunnen deze bedrijven een start betekenen voor jonge ondernemers (binnen of buiten de sector). Onder $3.000 \mathrm{~m}^{2}$ is op basis van algemene kennis en kennis over deze bedrijven ingeschat dat deze mogelijkheden er niet of nauwelijks zijn. Deze indeling van bedrijven is ook gehanteerd voor de intensiveringsgebieden binnen de Bommelerwaard.

Voor de overige gebieden in Gelderland was een inventarisatie vergelijkbaar aan die voor de Bommelerwaard niet zo gedetailleerd aanwezig. In eerste instantie is door de provincie een overzicht van glastuinbouwbedrijven aangereikt op basis van een registratie bij de Kamer van Koophandel. Dit overzicht bleek niet volledig. Voor deze gebieden is vervolgens door Glastuinbouw Nederland met info van lokale ondernemers in kaart gebracht welke bedrijven die in de buiten- en intensiveringsgebieden aanwezig zijn, in aanmerking kunnen komen voor de verplaatsingsregeling. 


\subsection{Beschrijving subsidieaanvragen}

In de periode 2009-2017 zijn door de provincie Gelderland 37 subsidieaanvragen voor bedrijfsverplaatsing ontvangen (zie bijlage 2 ). Hiervan zijn vijf aanvragen niet gehonoreerd. Van de 32 toegekende subsidieaanvragen zijn er twee niet doorgegaan, waardoor uiteindelijk 30 aanvragen zijn uitgevoerd. Bij de 30 uitgevoerde bedrijfsverplaatsingen was in totaal 108,5 ha te saneren oppervlakte betrokken, inclusief 51,2 ha aan ingebrachte sprokkellocaties. Sprokkellocaties zijn te saneren glasopstanden van andere eigenaren, die ingebracht kunnen worden in een aanvraag en waarvoor subsidie kan worden verkregen. Na verplaatsing is 99,6 ha aan 'nieuwbouw' teruggekomen (zie tabel 3.1).

Tabel 3.1 Overzicht kasoppervlakte behorend bij de aanvragen voor bedrijfsverplaatsing in de provincie Gelderland, periode 2009-2017 (ha en tussen haakjes aantal)

\begin{tabular}{|c|c|c|c|c|}
\hline Gewasgroep & $\begin{array}{l}\text { Oppervlakte vóór } \\
\text { bedrijfsverplaatsing }\end{array}$ & $\begin{array}{l}\text { Oppervlakte } \\
\text { sprokkellocaties }\end{array}$ & $\begin{array}{l}\text { Totaal te saneren } \\
\text { kasoppervlakte }\end{array}$ & $\begin{array}{l}\text { Oppervlakte ná } \\
\text { bedrijfsverplaatsing }\end{array}$ \\
\hline Pot- en perkplanten & $11,4(9)$ & $20,8(44)$ & 32,2 & 14,0 a) \\
\hline Snijbloemen & $43,6(19)$ & $26,6(52)$ & 70,2 & 70,4 \\
\hline $\begin{array}{l}\text { Vermeerdering en } \\
\text { veredeling }\end{array}$ & $2,2(2)$ & . & 2,2 & 2,4 \\
\hline Tuinplanten & $1,1(1)$ & $3,9(10)$ & 5,0 & 12,0 \\
\hline Gewas onbekend & $0,3(1)$ & . & 0,3 & 3,3 \\
\hline Totaal aanvragen & $60,7(37)$ & $54,3(113)$ & 115,0 & 117,0 \\
\hline $\begin{array}{l}\text { W.v. niet } \\
\text { gehonoreerd }\end{array}$ & $3,9(5)$ & $0,5(2)$ & 4,4 & 15,7 b) \\
\hline $\begin{array}{l}\text { W.v. gehonoreerd en } \\
\text { uitgevoerd }\end{array}$ & $57,3(30)$ & $51,2(109)$ & 108,5 & 99,6 \\
\hline
\end{tabular}

a) In één geval is vanwege het ontbreken van informatie aangenomen dat de oppervlakte in de nieuwe situatie identiek is aan die van de situatie vóór verplaatsing; b) Beoogde oppervlakte na verplaatsing.

Uit tabel 3.1 blijkt dat met name snijbloemen- en potplantenbedrijven $(n=28)$ een aanvraag voor de verplaatsingssubsidie hebben ingediend. Twee gehonoreerde aanvragen zijn uiteindelijk niet doorgegaan. Eén omdat de betrokken gemeente de grond niet wilde kopen, de ander vanwege het niet rond kunnen krijgen van de financiering voor verplaatsing.

Voor de afwijzing van vijf subsidieaanvragen zijn de volgende redenen vermeld:

- een te klein percentage eigendomsrechten. De aanvragende partij had een minderheidsaandeel in het bedrijf $(2 x)$

- het opvoeren van niet-subsidiabele kosten in de aanvraag (2x)

- het niet kunnen aantonen van de volwaardigheid van het bedrijf en in het bijzonder geen volledig inkomen uit het bedrijf voor ten minste één persoon $(1 \mathrm{x})$.

Van de toegekende subsidieaanvragen zijn er zeven in tweede instantie gehonoreerd. In één geval is de subsidie toegekend ná het aanleveren van door de provincie gevraagde additionele informatie (onbekend welke) en in een ander geval is de subsidieaanvraag na een bezwaarschrift alsnog gehonoreerd voor een hoger (maar niet het maximaal te verkrijgen) subsidiebedrag. Voor de andere 
vijf aanvragen werd deze in eerste instantie afgewezen, omdat het bedrijf de laatste drie jaar niet in (gedeeld) eigendom was van de aanvrager. Dit beoordelingscriterium is blijkbaar te strikt gehanteerd, want in tweede instantie werd de subsidieaanvraag wel toegekend ook al was het bedrijf minder dan drie jaar in eigendom van de indiener. Wel moest door de indiener worden aangetoond dat het bedrijf volwaardig was in de afgelopen drie jaar (met name inkomen voor minimaal één persoon), dus ook voor het voorgaande bedrijf. In al deze vijf gevallen betrof het aanvragen in de periode 2016-2017.

Onder de 32 gehonoreerde aanvragen zaten ook aanvragen waar het bij verplaatsing ging om uitbreiding van het betreffende bedrijf op een bestaande locatie $(n=7)$ of de aankoop van een bestaand bedrijf in een van de intensiveringsgebieden $(n=6)$. De rest betrof nieuwbouw in een intensiveringsgebied $(n=10)$. Van 9 aanvragen was dit niet op te maken uit de aangereikte informatie.

Om extra subsidie te kunnen verkrijgen was het voor te verplaatsen bedrijven mogelijk zogenaamde sprokkellocaties te vergaren. Sprokkellocaties zijn verouderde kassen die gesitueerd zijn buiten de vijf concentratiegebieden. In totaal zijn 109 sprokkellocaties ingebracht door de bedrijven waarvan de aanvraag is toegekend en is uitgevoerd. Het aantal sprokkellocaties per aanvraag liep uiteen van één tot tien.

Het aantal bedrijven dat in de periode 2009-2017 meer dan één aanvraag voor verplaatsingssubsidie heeft ingediend is niet bekend, omdat verschillende bedrijfsnamen voorkwamen in de subsidieaanvragen. Van één eigenaar met meerdere bedrijven is bekend dat het tweemaal een aanvraag heeft ingediend.

\subsection{Beoordelingscriteria doel verplaatsing}

\subsubsection{Volwaardigheid bedrijf}

\section{Continuïteit van het bedrijf}

De 37 aanvragen waren bij indiening vergezeld van diverse documenten (zie bijlage 3). In de door de provincie Gelderland aangereikte documenten ontbraken in een aantal gevallen voor deze evaluatie met name de financiële verslagen of waren de financiële gegevens niet volledig. Het kwam voor dat één of twee boekjaren ontbraken, dat de exploitatierekening ontbrak of dat een financiële prognose + argumentatie van de nieuwe situatie ontbrak (zie tabel 3.2).

Tabel 3.2 Mate van volledigheid financiële gegevens van de ingediende aanvragen over de periode 2009-2017 (aantal; tussen haakjes aantal niet gehonoreerde aanvragen)

\begin{tabular}{clcc}
$\begin{array}{l}\text { Van minstens twee } \\
\text { boekjaren beschikbaar, } \\
\text { inclusief prognose }\end{array}$ & $\begin{array}{l}\text { Van één boekjaar } \\
\text { beschikbaar, inclusief } \\
\text { prognose }\end{array}$ & $\begin{array}{l}\text { Beperkte financiële } \\
\text { Informatie beschikbaar }\end{array}$ & $\begin{array}{l}\text { Financiële informatie niet } \\
\text { beschikbaar }\end{array}$ \\
\hline 10 & 6 & $10(1)$ & $11(4)$ \\
\hline
\end{tabular}

Voor deze evaluatie ontbrak voor een substantieel aantal aanvragen de benodigde financiële informatie om de gewenste analyse en evaluatie te kunnen uitvoeren.

De financiële informatie moet door de aanvragers wel aan de provincie zijn aangeleverd bij indiening, omdat dit is vereist bij de (digitale) subsidieaanvraag.

\section{Rentabiliteit en solvabiliteit}

In 2.1.2 zijn voor het beoordelen van het criterium continuïteit van het bedrijf de indicatoren rentabiliteit en solvabiliteit gekozen. Op basis van de beschikbare financiële gegevens zijn de gemiddelde rentabiliteit en solvabiliteit bepaald (zie tabel 3.3). 
Tabel 3.3 Indeling van bedrijven naar rentabiliteit (gemiddelde over drie jaar) en naar solvabiliteit in het jaar voorafgaand aan de bedrijfsverplaatsing (aantal)

\begin{tabular}{|c|c|c|c|c|}
\hline Rentabiliteit & Lager dan $95 \%$ & Tussen 95 en $100 \%$ & Hoger dan $100 \%$ & $\begin{array}{l}\text { Informatie niet } \\
\text { aanwezig }\end{array}$ \\
\hline Aantal & 2 & 3 & 18 & 14 \\
\hline Aantal & 4 & 6 & 10 & 17 \\
\hline
\end{tabular}

Opmerking: Van een substantieel aantal bedrijven kon de rentabiliteit en solvabiliteit niet worden bepaald.

Uit tabel 3.3. volgt dat er twee bedrijven zijn met een rentabiliteit lager dan $95 \%$ en 10 bedrijven met een solvabiliteit onder de $30 \%$. Het is duidelijk dat de bedrijven in de groep met slechtste financiële cijfers niet zomaar weer financieel gezond zullen worden, ook niet door een bedrijfsverplaatsing.

Nadere analyse leert dat één bedrijf met de laagste gemiddelde rentabiliteit (lager dan 95\%) een solvabiliteit heeft lager dan $10 \%$. Aan dit bedrijf is wel subsidie verleend en is de bedrijfsverplaatsing ook doorgegaan. Op basis van enkel het criterium solvabiliteit (lager dan 30\%) zou ook voor negen andere bedrijven de vraag kunnen worden gesteld of de subsidie toegekend had mogen worden. Voor deze bedrijven waren de stille reserves niet bekend om na te gaan of daarmee hun solvabiliteit alsnog boven de $30 \%$ uitkomt.

Van één bedrijf is bekend dat het de verplaatsing ondanks de subsidiebeschikking niet heeft kunnen financieren, ondanks dat het een goede solvabiliteit had (>30\%). De reden hiervoor is echter bij Wageningen Economic Research niet bekend.

In één aanvraag was het verhogen van de solvabiliteit blijkbaar een argument voor het aanvragen van de verplaatsingssubsidie om zodoende een hypothecaire lening te verkrijgen.

\section{Werkgelegenheid voor minimaal één persoon}

Met betrekking tot de werkgelegenheid voldoen de bedrijven waarover deze informatie bekend is $(n=21)$ aan de voorwaarde dat een bedrijf ten minste $1 \mathrm{fte}$ werkgelegenheid dient te bieden. Dit blijkt uit de kosten voor arbeid in de fiscale exploitatierekening. Voor de bedrijven lag deze ruim (met een minimum van circa 100.000 euro in het laatste jaar) boven het gehanteerde normbedrag van $€ 28.500$,- per jaar. Bij eenmanszaken, vennootschappen onder firma of maatschappen was de fiscale winst over meerdere jaren maatgevend.

\section{Inkomen voor minimaal één persoon}

Op grond van de beschikbare fiscale exploitatierekeningen kan worden afgeleid dat op 21 bedrijven een inkomen voor minimaal één persoon werd gegenereerd. De arbeidskosten bedroegen op deze bedrijven meer dan het gehanteerde normbedrag voor de vergoeding van de arbeid van de ondernemer van $€ 50.000$,- per jaar.

Van de overige aanvragen zijn geen arbeidskosten bekend, omdat de fiscale exploitatierekening ontbreekt. Ook ontbreekt daarmee het fiscale bedrijfsresultaat (winst).

Als subsidieaanvragen door de provincie worden toegekend, dan voldoen de aanvragen in beginsel aan het inkomenscriterium. Van de 5 afgewezen subsidieaanvragen was het niet voldoen aan het inkomenscriterium in één geval een reden voor afwijzing. De afwijzing betrof in eerste instantie een aanvraag waarbij het bedrijf van de aanvrager minder dan drie jaar volwaardig in gebruik was. Dit betrof een subsidieaanvraag voor de verplaatsing van een opgekocht bedrijf in het extensiveringsgebied door een bedrijf dat al in het intensiveringsgebied is gevestigd. Na een bezwaarschift van de aanvrager is het inkomen uit het opgekochte bedrijf in het extensiveringsgebied door de provincie niet volwaardig beoordeeld. In een bezwaarprocedure is de provincie door de rechtbank in het gelijk gesteld. ${ }^{2}$

2 https://uitspraken.rechtspraak.nl/inziendocument?id=ECLI:NL:RBGEL:2018:1344 


\subsubsection{Verplaatsing van het gehele bedrijf}

Bij alle 32 toegekende subsidieaanvragen was er een verplaatsing van de betreffende bedrijfslocatie. Dit betekent dus sanering van het glas op de bedrijfslocatie waar de aanvraag betrekking op heeft en de eventueel ingebrachte sprokkellocaties.

De daaruit resulterende nieuwbouw (in de meerderheid van de gevallen), uitbreiding op de bestaande locatie of aankoop van een locatie in het intensiveringsgebied had minimaal dezelfde oppervlakte glas als het glasoppervlak op de eigen bedrijfslocatie (zie ook tabel 3.1).

\subsubsection{Behoud van het eigenaarschap}

Van twee aanvragen is de subsidie in de periode 2009-2017 afgewezen, omdat het aandeel van de aanvrager in het eigenaarschap van het bedrijf te laag was (minder dan 50\%). Deze aanvragen hadden betrekking op hetzelfde bedrijf met een minderheidsaandeel van de ondernemer van $20 \%$.

Van de overige aanvragen is mede op basis van de aanwezige uittreksels van Kamer van Koophandel geen (ingrijpende) wijziging in het eigenaarschap opgetreden. Hiermee wordt ook de vraag beantwoord dat wijzigingen in het eigenaarschap na bedrijfsverplaatsing geen trend is (geworden).

In de periode 2016-2017 zijn vijf aanvragen ingediend waarbij het te verplaatsen bedrijf minder dan drie jaar in (gedeelde) eigendom was van de aanvrager. Deze situatie kwam niet voor in de periode 2009-2015. Aanvankelijk werden deze aanvragen afgewezen, maar na bezwaar zijn de aanvragen alsnog gehonoreerd. De Commissie Rechtsbescherming oordeelde dat in de regeling niet duidelijk was geformuleerd dat de aanvrager ook drie jaar eigenaar (of pachter) van het te verplaatsen bedrijf moest zijn en stelde de eiser(s) in het gelijk. De provincie heeft het advies van de commissie overgenomen.

\subsubsection{Behoud van de teelt(richting)}

Van twee bedrijven kon het geteelde product na de verplaatsing niet worden achterhaald (informatie niet beschikbaar).

Van de overige 35 subsidieaanvragen is in de periode 2009-2017 in vier gevallen de teeltrichting gewijzigd of zou die worden gewijzigd. Dit betrof enerzijds een overname van een bedrijf in het intensiveringsgebied met een andere teelt, dat vervolgens is gecontinueerd. Anderzijds betrof het aangekochte bedrijven buiten de intensiveringsgebieden, die na de (beoogde) verplaatsing naar het intensiveringsgebied van teeltrichting zouden veranderen.

Een wijziging van teeltrichting bij verplaatsing is daarmee geen trend. Overigens is dit geen criterium in de beoordeling van de subsidieaanvraag.

\subsubsection{Samenvatting}

Helaas waren niet van alle subsidieaanvragen voor de verplaatsingsregeling de financiële informatie (volledig) beschikbaar voor deze evaluatie.

Op basis van de resultaten in de vorige paragrafen kan worden afgeleid dat van de 32 gehonoreerde aanvragen (inclusief intrekkingen) één aanvraag niet aan de intrinsieke doelen van de verplaatsingsregeling lijkt te voldoen. Dit is de aanvraag waarin niet voldaan wordt aan de continuïteit (ontoereikende rentabiliteit én solvabiliteit) en daarmee aan de volwaardigheid van het bedrijf. De andere subcriteria van volwaardigheid van het bedrijf (arbeidsinzet en inkomen voor één persoon) lijken geen aanleiding te geven om toegekende aanvragen anders te beoordelen. De criteria verplaatsing gehele bedrijf, behoud eigenaarschap en behoud teeltrichting vormen ook geen aanleiding om een gehonoreerde aanvraag alsnog 'af te wijzen'. 
In de periode 2016-2017 waren er relatief meer aanvragen, waarvan het (gedeeld) eigendom of pacht minder dan drie jaar bij de aanvrager lag. Na een bezwaarprocedure zijn de aanvragen alsnog toegewezen, omdat in de regeling niet duidelijk was geformuleerd dat de aanvrager drie jaar eigenaar of pachter moest zijn van het te verplaatsen bedrijf. Of deze ontwikkeling een trend wordt, valt moeilijk een uitspraak over te doen.

\subsection{Potentiële aanvragen voor verplaatsing}

\section{Inleiding}

Het totaal aantal bedrijven met tuinbouw onder glas in Gelderland bedroeg 330 in 2017 met een oppervlakte glas van 452,6 ha (CBS, 2018). Het aantal gespecialiseerde glastuinbouwbedrijven (bedrijven met $2 / 3$ deel van de standaardopbrengst uit een bepaalde teelt, CBS) was 212 met een totaal oppervlakte glas van 391,7 ha. Van de gespecialiseerde glastuinbouwbedrijven hadden 163 bedrijven meer dan 0,5 ha glasoppervlak. Op de gespecialiseerde glastuinbouwbedrijven (groter dan 0,5 ha glas) is voor circa $70 \%$ bedrijfsopvolging aanwezig (ondernemer jonger dan 51 jaar of een opvolger aanwezig). Zoals in paragraaf 2.2 vermeld, kan met de CBS-cijfers geen onderscheid worden gemaakt tussen extensiverings- en intensiveringsgebieden.

Volgens informatie van de provincie Gelderland (Omgevingsvisie) zijn er 281 glastuinbouwbedrijven in 2018 (bron: bedrijven met registratie bij Kamer van Koophandel met teelt onder glas). Deze zijn op te splitsen in 194 bedrijven in de buitengebieden (inclusief extensiveringsgebieden) en 87 bedrijven in de (reserve) glastuinbouwconcentratiegebieden (inclusief regionaal cluster). Volgens de adviseurs zijn er meer bedrijven of bedrijfslocaties met glastuinbouw. Een aantal tuinbouwbedrijven met glas ontbreekt in het overzicht van de provincie. Dit zullen waarschijnlijk circa 50 bedrijven zijn als van de CBSgegevens wordt uitgegaan $(=330-281)$.

\section{Schatting aantal bedrijven met potentie tot verplaatsing}

In paragraaf 2.2 is een aanpak beschreven waarbij met de adviseurs het aantal potentiële verplaatsers is bepaald voor de verschillende gebieden in Gelderland (zie tabel 3.4). Het bleek dat voor de gebieden buiten de Bommelerwaard niet duidelijk was welke bedrijven tussen 3.000 en $5.000 \mathrm{~m}^{2}$ potentiële verplaatsers zouden kunnen zijn. In dit kader zijn daarom alleen bedrijven groter dan $5.000 \mathrm{~m}^{2}$ in beschouwing genomen. Bij deze beoordeling zijn de toetsingscriteria van de verplaatsingsregeling impliciet meegenomen: met andere woorden dat de potentieel te verplaatsen bedrijven volgens de adviseurs aan de criteria van de verplaatsingsregeling zouden voldoen.

Tabel 3.4 Geschatte aantal glastuinbouwbedrijven $\left(>5.000 \mathrm{~m}^{2}\right)$ in de buitengebieden en intensiveringsgebieden in Gelderland dat potentieel in aanmerking komt voor de verplaatsingsregeling

\begin{tabular}{lccc} 
Gebied & Buitengebied a) & Intensiveringsgebied b) & 109 \\
Bommelerwaard & 49 & 60 & 12 \\
\hline $\begin{array}{l}\text { West Gelderland (exclusief } \\
\text { Bommelerwaard) }\end{array}$ & 10 & 2 & 13 \\
\hline $\begin{array}{l}\text { Midden, Oost en Noord Gelderland } \\
\text { (inclusief Next Garden) }\end{array}$ & 49 & & 62 \\
\hline Totaal & 108 & 75 & 183 \\
\hline
\end{tabular}

a) Buitengebied, inclusief extensiveringsgebied: solitaire vestiging; b) Intensiverings- of glastuinbouwconcentratiegebied: inclusief reserve concentratiegebied; te herstructureren bedrijven.

De aandacht van de provincie gaat in eerste instantie uit naar potentiële verplaatsers buiten de glastuinbouwconcentratiegebieden (solitair gelegen). Daar ligt de focus vanuit de verplaatsingsregeling (sanering van verspreid liggende glas). Daarnaast is de provincie belangstellend naar de omvang van het aantal bedrijven dat in de intensiveringsgebieden aanspraak zou kunnen maken op de verplaatsingsregeling met het oog op herstructurering. 
Uit tabel 3.4 volgt dat er buiten de glastuinbouwconcentratiegebieden volgens schatting ruim 100 bedrijven ( $g r o t e r$ dan $5.000 \mathrm{~m}^{2}$ ) zijn die volgens de adviseurs in aanmerking komen voor de verplaatsingsregeling en daarom potentiële verplaatsers zijn.

In de intensiveringsgebieden gaat het om circa 75 bedrijven, die mogelijk voor de verplaatsingsregeling in aanmerking komen om daarmee de herstructurering van het intensiveringsgebied te bevorderen.

Bij de schatting van potentiële verplaatsers is door de adviseurs ook nagegaan of er sprokkelglas aanwezig is in de gebieden dat in een aanvraag voor verplaatsing kan worden meegenomen. In alle gebieden in Gelderland zou nog sprokkelglas aanwezig zijn. Voor de buitengebieden in de Bommelerwaard betreft dit sprokkelglas op circa 60 bedrijven met een glasoppervlak van minder dan $3.000 \mathrm{~m}^{2}$ (gemiddeld $1.200 \mathrm{~m}^{2}$ per bedrijf; info PHTB). Voor de andere gebieden in Gelderland is dit aantal bedrijven niet bekend. 


\section{Conclusies}

Beoordeling intrinsieke doel regeling Verplaatsing glastuinbouwbedrijven Gelderland

De aanvragen voor de regeling Verplaatsing glastuinbouwbedrijven van de provincie Gelderland zijn met betrekking tot het intrinsieke doel van de regeling in deze studie beoordeeld op de volgende criteria: volwaardigheid bedrijf, verplaatsing gehele bedrijf, behoud eigenaarschap en behoud teeltrichting.

Uit analyse van alle aanvragen voor de regeling Verplaatsing glastuinbouwbedrijven Gelderland in de periode 2009-2017 bleek dat van de 32 gehonoreerde aanvragen (inclusief intrekkingen) er één aanvraag niet lijkt te voldoen aan het intrinsieke doel van de regeling. Deze aanvraag voldoet niet aan het beoordelingscriterium volwaardigheid van het bedrijf en in het bijzonder de continuïteit van het bedrijf in de laatste drie jaar. Alle gehonoreerde aanvragen bleken wel te voldoen aan de andere genoemde beoordelingscriteria.

In de periode 2016-2017 blijken meer aanvragen te zijn geweest dan de periode daarvoor, waarvan het (gedeeld) eigendom of pacht minder dan drie jaar bij de aanvrager lag. In eerste instantie werden deze aanvragen hierop afgewezen, maar werden na herbeschikking alsnog toegekend. In de verplaatsingsregeling was volgens de Commissie Rechtsbescherming niet duidelijk geformuleerd dat de aanvrager gedurende drie jaar vóór de aanvraag ook eigenaar of pachter moest zijn van het te verplaatsen bedrijf.

Potentieel aantal bedrijven voor de regeling Verplaatsing glastuinbouwbedrijven Gelderland Geschat wordt dat rond de 100 bedrijven met tuinbouw onder glas in de buitengebieden (inclusief extensiveringsgebieden) in Gelderland in aanmerking kunnen komen voor de regeling Verplaatsing glastuinbouwbedrijven Gelderland. Dit is een substantieel aantal.

Ook in de intensiverings- of glastuinbouwconcentratiegebieden is een substantieel aantal bedrijven (circa 75) dat mogelijk in aanmerking komt voor de verplaatsingsregeling, waarmee de herstructurering in de intensiveringsgebieden kan worden gestimuleerd.

De regeling Verplaatsing glastuinbouwbedrijven in Gelderland kan ook de komende jaren nog van waarde zijn voor de modernisering en herstructurering van de glastuinbouw en voor de verbetering van de ruimtelijke kwaliteit van gebieden waar solitaire glastuinbouwbedrijven nu nog gelegen zijn. 


\section{Literatuur en websites}

Meulen, H. van der, K. de Bont, H. Agricola, P. van Horne, R. Hoste, A. van der Knijff, F. Leenstra, R. van der Meer en A. de Smet, Schaalvergroting in de land en tuinbouw; Effecten bij de veehouderij en glastuinbouw, LEI Rapport 2010-094, Den Haag 2010.

Provincie Gelderland. Vertrouwelijke info subsidieaanvragen verplaatsingsregeling periode 2009-2017. Provincie Gelderland, 2018.

Vermeulen, P. (2016). Kwantitatieve Informatie voor de Glastuinbouw 2016-2017. Kengetallen voor Groenten-Snijbloemen-Pot- en Perkplantenbedrijven. Editie 25. Wageningen Plant Research, Bleiswijk.

\section{Websites}

www.cbs.nl 


\section{Bijlage 1 Geraadpleegde deskundigen}

\begin{tabular}{ll}
$\begin{array}{l}\text { Naam } \\
\text { Matthieu Opdam } \\
\text { Eric Goesten }\end{array}$ & Bedrijf \\
\hline Thijs van Giessen & Adviseur \\
\hline Jack Beerkens & Beerkens Subsidie- en bedrijfsadvies \\
\hline Teun Biemond & PHTB (Projectbureau Herstructurering Tuinbouw Bommelerwaard) \\
\hline Thijs Zee & Gemeente Lingewaard \\
\hline Harrie Vreman & Glastuinbouw Nederland \\
\hline Gerard Selman & Glastuinbouwpact Bommelerwaard \& Neerijnen \\
\hline
\end{tabular}




\section{Bijlage 2 Overzicht subsidieaanvragen regeling Verplaatsing glastuinbouwbedrijven Gelderland}

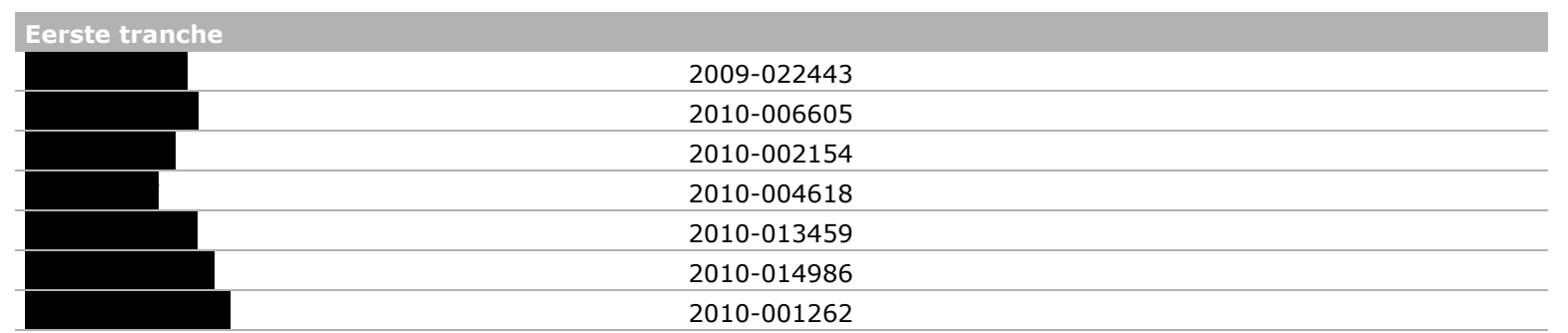

\section{Tweede tranche}

\begin{tabular}{|l|l|l}
\hline & \\
\hline & \\
\hline
\end{tabular}

2011-001192

2011-001186 2011-001155 2011-001077 2011-001194 2011-001504

Derde tranche (Vliegende start)

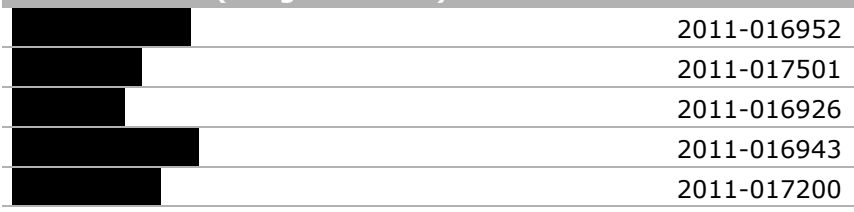

Vierde tranche (tender 2013)

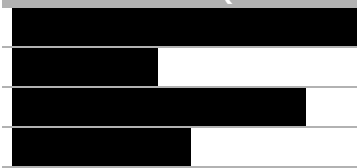

2013-012540

2013-012534

2013-011980

2013-012531

Vijfde tranche (1e tender 2014)

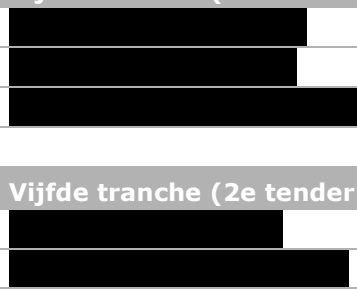

2014-009119

2014-009727

2014-009749

2014-016528

2014-016527

Zesde tranche POP3 1 tender 2016

nog niet beschikt

\section{Zevende tranche POP3 1 tender 2017}

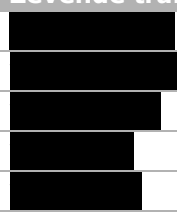

17658000007

17658000012

17658000010

17658000006

17658000008 


\section{Bijlage 3 Documenten vereist bij indienen subsidieaanvraag voor Verplaatsing glastuinbouwbedrijven Gelderland}

Bij iedere (digitale) aanvraag voor de regeling Verplaatsing glastuinbouwbedrijven Gelderland horen (verplichte) bijlagen met achtergrondinformatie. De volgende bijlagen zijn vereist:

- Motivatie

- Situatieschets bestaande bedrijf/situatieschets nieuw bedrijf

- Eigendom-/pachtsituatie

- Plattegronden

- Uittreksel kamer van koophandel

- Betaling afschrift van bank

- Financieel verslag(en) met gegevens van drie recente jaren

- Financiële prognose nieuwe situatie met argumentatie. 
Wageningen Economic Research Postbus 29703

2502 LS Den Haag

T 0703358330

Ecommunications.ssg@wur.nl

www.wur.nl/economic-research

Wageningen Economic Research NOTA

2019-047
De missie van Wageningen University \& Research is 'To explore the potential of nature to improve the quality of life'. Binnen Wageningen University \& Research bundelen Wageningen University en gespecialiseerde onderzoeksinstituten van Stichting Wageningen Research hun krachten om bij te dragen aan de oplossing van belangrijke vragen in het domein van gezonde voeding en leefomgeving. Met ongeveer 30 vestigingen, 5.000 medewerkers en 10.000 studenten behoort Wageningen University \& Research wereldwijd tot de aansprekende kennisinstellingen binnen haar domein. De integrale benadering van de vraagstukken en de samenwerking tussen verschillende disciplines vormen het hart van de unieke Wageningen aanpak. 


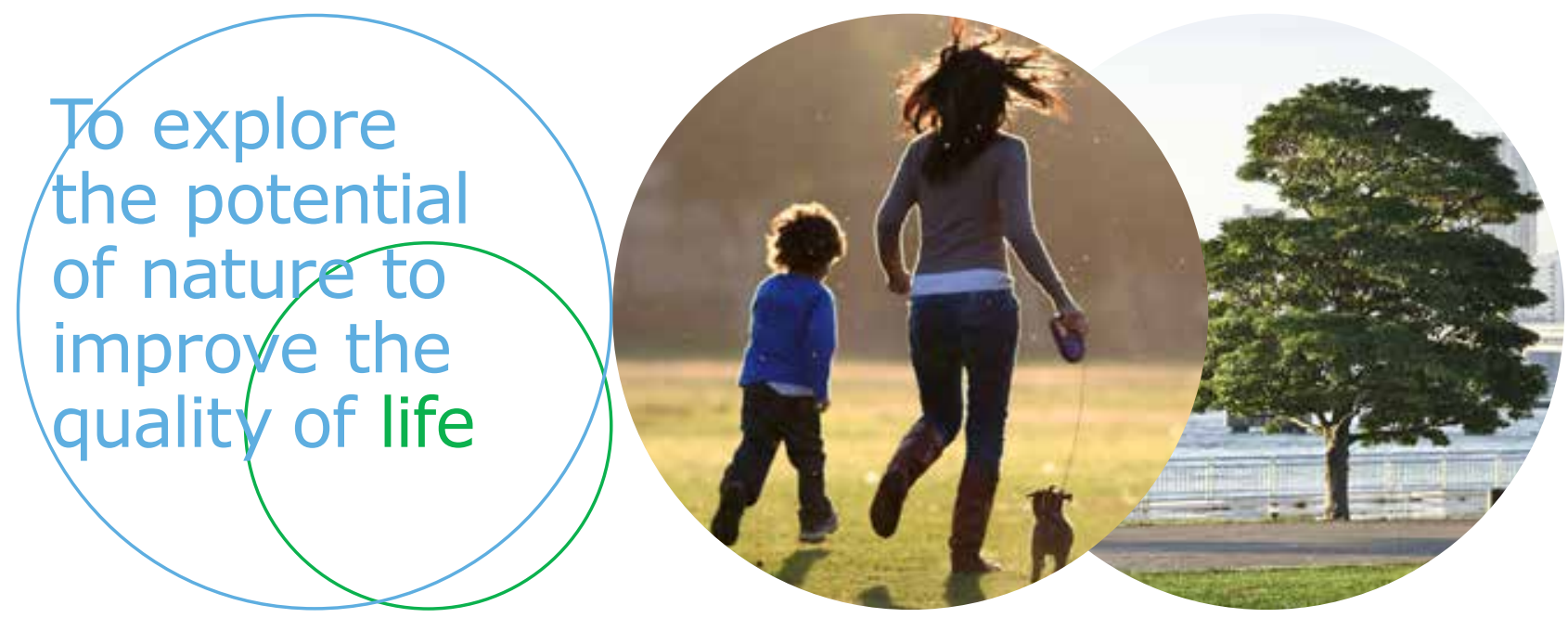

Wageningen Economic Research Postbus 29703

2502 LS Den Haag

E communications.ssg@wur.nl

$T+31(0) 703358330$

www.wur.nl/economic-research

De missie van Wageningen University \& Research is 'To explore the potential of nature to improve the quality of life'. Binnen Wageningen University \& Research bundelen Wageningen University en gespecialiseerde onderzoeksinstituten van Stichting Wageningen Research hun krachten om bij te dragen aan de oplossing van belangrijke vragen in het domein van gezonde voeding en leefomgeving. Met ongeveer 30 vestigingen, 5.000 medewerkers en 10.000 studenten behoort Wageningen University \& Research wereldwijd tot de aansprekende kennis-

Nota 2019-047 instellingen binnen haar domein. De integrale benadering van de vraagstukken en de samenwerking tussen verschillende disciplines vormen het hart van de unieke Wageningen aanpak. 